Journal of Animal and Veterinary Advances 10 (5): 610-613, 2011

ISSN: $1680-5593$

(C) Medwell Journals, 2011

\title{
A Mutation at Exon 3 of $K I F-1$ Gene of Three Goat Breeds in China
}

\author{
${ }^{1}$ Liu Wu-Jun, ${ }^{1}$ Wang Qiong, ${ }^{1}$ Huang Xi-Xia, ${ }^{1}$ Yu Shi-Gang and ${ }^{2}$ Tian Ke-Chuan \\ ${ }^{1}$ College of Animal Science, Xinjiang Agricultural University, Urumqi, 830052 Xinjiang, China \\ ${ }^{2}$ Xinjiang Academy of Animal Science, Urumqi, 830000 Xinjiang, China
}

\begin{abstract}
Keratin Intermediate-Filament (KIF) proteins form the main structural elements of a wool fibre. In this study, PCR-RFLP and DNA sequencing methods were used to detect polymorphisms of $K I F-1$ gene in 786 samples of 3 Xinjiang local goat breeds (Xinjiang, Nanjiang Cashmere and Bogeda Cashmere goat). The results showed that KIF-1-P3 locus has polymorphisms. The frequencies of genotype AA were $0.675,0.577$ and 0.766 , genotype $\mathrm{AB}$ were $0.296,0.400$ and 0.234 , genotype $\mathrm{BB}$ were $0.030,0.023$ and 0.000 for Xinjiang, Nanjiang Cashmere and Bogeda Cashmere goat breeds, respectively. The genotypic distributions were in disagreement with Hardy-Weinberg equilibrium in Nanjiang Cashmere goat breed. In addition, the mutation was detected at KIF-1-P3 locus by DNA sequencing method, a novel of SNP was revealed in exon 3 (Genebank M23912: c.3212 $\mathrm{C}>\mathrm{T}$ ) and it belongs to synonymous mutation. However, there is no significant difference in Xinjiang goat breed between polymorphisms of the $K I F-1$ gene and cashmere production traits (fineness, thickness, yield and body weight after combing). Moreover, analysis of variance indicated that various genotypes in the 3 Xinjiang goat breeds were highly significant $(\mathrm{p}<0.01)$.
\end{abstract}

Key words: $K I F-1$ gene, PCR-RFLP, polymorphism, SNP, genotype, frequencies

\section{INTRODUCTION}

The wool fibre has a complex morphology consisting of an outer layer of cuticle scales surrounding an inner cortex (Hocker, 2002; Leeder, 1986; Rippon, 1992). The proteins of wool are products of several gene families each having a number of closely related members (Powell and Rogers, 1996). Keratins, a family of Intermediate Filament (IF) proteins are primarily involved in the mechanical and structural functions of epithelial tissue (Hatzfeld and Franke, 1985). The content of keratin in wool fibre structure can account for $99 \%$. So keratins are most likely playing an important role in the control of wool traits.

It is known that keratins can be classified as Keratin Intermediate-Filament (KIF) proteins and KeratinAssociated Proteins (KAP). Keratin intermediate-filament is low-sulfur proteins classified into type I keratins (acidic) and type $\Pi$ keratins (non-acidic) (Schweizer et al., 2006; Powell, 1996) with $>50$ genes encoding these proteins in vertebrates (Pruett et al., 2004). To date, a wide variety of keratin and keratin-related genes have been reported (Rogers et al., 2004, 2005, 2006).

However, the reports about the polymorphism of $\mathrm{KAP}$ are much more than that of KIF. In the present study, the polymorphism of $K I F-1$ gene was analyzed as a genetic marker candidate for growth traits in 3 Xinjiang local goat breeds (Xinjiang, Nanjiang Cashmere and
Bogeda Cashmere goat). It can provide reference in cashmere production and other performance for animal breeding and genetics.

\section{MATERIALS AND METHODS}

Animal source: In this study, data on cashmere traits and genomic DNA samples were obtained from 786 individuals belonging to 3 Xinjiang local goat breeds (Xinjiang goat, $\mathrm{n}=203$; Nanjiang Cashmere goat, $\mathrm{n}=305$; Bogeda Cashmere goat, $n=278$ ). Xinjiang goat were from the breeding centre of Luntai of Xinjiang in China; Nanjiang cashmere goat were from AkeSu goat Research Center of Xinjiang and Bogeda cashmere goat were from Breeding Farm of Bogeda goat in Urumuqi.

DNA preparation: Genomic DNA of 786 cashmere goat were isolated from $2 \%$ heparin-treated blood samples and stored at $-80^{\circ} \mathrm{C}$ following standard procedures (Sambrook and Russell, 2001).

Primer design and PCR amplification: According to the sequence of KIF-1 (GenBank accession number M23912), one pair of PCR primers was designed with Primer 5.0 as follow:

Forward: 5'-TCAAACCAAACTAGAGTCAAGG-3, Reverse: 5'-CAGATTCTTTGACTAGTTGAGC-3,

Corresponding Author: Tian Ke-Chuan, Xinjiang Academy of Animal Science, Urumqi, 830000, Xinjiang, China 
They were used to amplify 298 bp PCR products containing for Capra $K I F-1$ gene partial of intron 2, exon 3 and partial of intron 3 locus (P3 locus). One pair of PCR primers was designed using primer 5.0 software to amplify the coding and flanking region of Capra $K I F-1$ gene, the size of PCR products was $298 \mathrm{bp}$. The $25 \mu \mathrm{L}$ volume contained: 50 ng genomic DNA, $0.5 \mu \mathrm{M}$ of each primer, $1 \times$ Buffer (including $1.5 \mathrm{mM} \mathrm{MgCl}_{2}$ ), $200 \mu \mathrm{M} \mathrm{dNTPs}$ and 0.625 units of Taq DNA polymerase (MBI). The PCR was performed using the following program: $94^{\circ} \mathrm{C}$ for $5 \mathrm{~min}, 35$ cycles of $94^{\circ} \mathrm{C}$ for $40 \mathrm{sec}$, annealing $61^{\circ} \mathrm{C}$ for $35 \mathrm{sec}, 72^{\circ} \mathrm{C}$ for $35 \mathrm{sec}$ and a final extension at $72^{\circ} \mathrm{C}$ for $10 \mathrm{~min}$.

PCR-RFLP and DNA sequencing: Aliquots of $10 \mu \mathrm{L}$ PCR products of $K I F-1$ gene were incubated with 6 units restriction enzyme Hae $\beta$ (MBI fermentas) for $8 \mathrm{~h}$ at $37^{\circ} \mathrm{C}$ then electorphoresed on $2 \%$ agarose gel stained with $1 \times$ TBE buffer ( $89 \mathrm{mM}$ Tris, $89 \mathrm{mM}$ boric acid and $2 \mathrm{mM}$

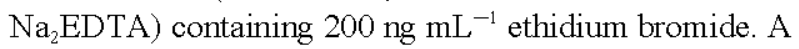
$6 \mu \mathrm{L}$ aliquot of PCR products was added to $1.5 \mu \mathrm{L}$ of loading dye $(0.025 \%$ bromophenol blue, $0.025 \%$ xylene cyanol, $40 \%, \mathrm{w} / \mathrm{v}$ sucrose) and the gels were run at a constant voltage $(120 \mathrm{~V})$ for $0.2 \sim 0.3 \mathrm{~h}$.

The PCR fragments from different patterns in the 3 breeds were amplified by the pair of primers were sequenced with BioXM software (version 2.6).

Statistical methods and analysis: About 3 indigenous goat breeds populations and differences genotypic frequencies at KIF-I-P3 locus were analyzed with SPSS software (versionl 6.0) (Norusis, 2008). He (gene heterozygosity), Ho (gene homozygosity), Ne (effective allele numbers) and PIC (Polymorphism Information Content) were calculated according to Nei and Roychoudhury (1974), Nei and Li (1979), respectively.

$$
\mathrm{H}_{0}=\sum_{\mathrm{i}=1}^{\mathrm{n}} \mathrm{P}_{\mathrm{i}}^{2}, \mathrm{H}_{\mathrm{e}}=1-\sum_{\mathrm{i}=1}^{\mathrm{n}} \mathrm{P}_{\mathrm{i}}^{2}
$$

The linear model was used in analyses of the impact of KIF-1 genotype and included effects of ewe, ram within ewe, age and genotype as well as interaction between ram and genotype was involved (Zhao et al., 2004).

Where:

$$
\mathrm{Y}_{\mathrm{ijk \textrm {km }}}=\mu+\mathrm{S}_{\mathrm{i}}+\mathrm{D}_{\mathrm{ij}}+\mathrm{A}_{\mathrm{k}}+\mathrm{G}_{1}+(\mathrm{SG})_{\mathrm{il}}+\mathrm{E}_{\mathrm{ij \textrm {kl } m}}
$$

$Y_{\mathrm{j} j \mathrm{klm}}=$ The trait measured on each of the ijklmth animal

$\mu \quad=$ The overall population mean

$\mathrm{S}_{\mathrm{i}}=$ The fixed effect associated with the ith ram

$D_{i j} \quad=$ The fixed effect associated with jth ewe with ram i

$\mathrm{A}_{\mathrm{k}}=$ Fixed effect due to the kth age
$\mathrm{G}_{1} \quad=$ The fixed effect associated with 1 th genotype (IGF-1/AA, AB and BB genotype)

$(\mathrm{SG})_{i 1}=$ Interaction between the ith ewe and the 1th genotype

$E_{\mathrm{jiklm}}=$ The random error

\section{RESULTS}

DNA sequencing analysis showed at KIF-1-P3 locus, there was a mutation (Genebank M23912: c.3212 C>T) in exon 3 region and it belongs to synonymous mutation (Fig. 1). The PCR product was amplified by one pair of PCR primers and its size was 298 bp (Fig. 2). By PCR-RFLP method, there were three genotypes (named as genotype $\mathrm{AA}, \mathrm{AB}$ and $\mathrm{BB}$ ) (Fig. 3).

Genotype and allele frequencies of KIF-1-P3 locus in the 3 breeds were showed in Table 1. Table 1 demonstrated A allele and AA genotype were predominant in the 3 Xinjing local goat breeds. Gene Homozygosity (Ho), gene Heterozygosity (He), effective

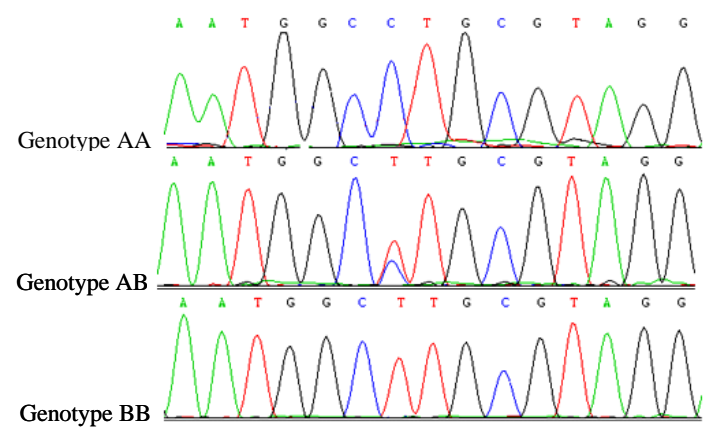

Fig. 1: DNA sequencing results of different genotypes at KIF-1-P3 locus

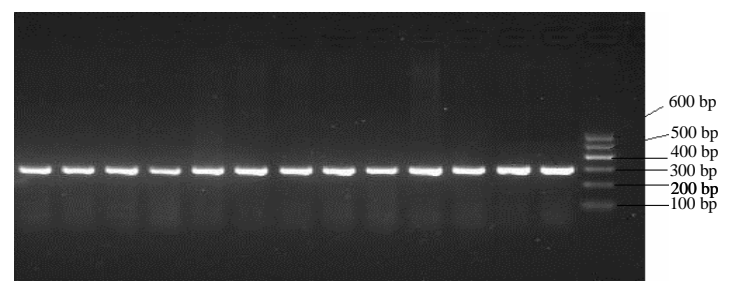

Fig. 2: Detection of PCR product of the KIF-1-P3 locus

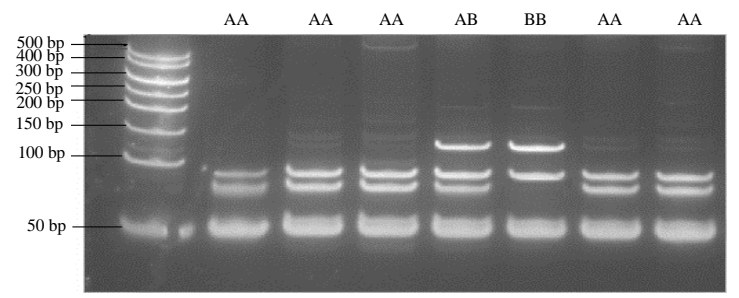

Fig. 3: PCR-RFLP patterns of HaeIII digesting KIF-1-P3 locus 
Table 1: Genotype distribution and allelic frequencies at the KIF-1-P3 locus

\begin{tabular}{|c|c|c|c|c|c|c|}
\hline \multirow[b]{2}{*}{ Breeds } & \multicolumn{3}{|c|}{ Genotype and genotype frequencies } & \multirow[b]{2}{*}{ No } & \multicolumn{2}{|c|}{ Allele frequencies } \\
\hline & $\mathrm{AA}$ & $\mathrm{AB}$ & $\mathrm{BB}$ & & A & $\mathrm{B}$ \\
\hline Xinjiang goat & $137(0.675)$ & $60(0.2960)$ & $6(0.030)$ & 203 & 0.823 & 0.177 \\
\hline Nanjiang cashmere goat & $176(0.577)$ & $122(0.4000)$ & $7(0.023)$ & 305 & 0.777 & 0.223 \\
\hline Bogeda cashmere goat & $213(0.766)$ & $65(0.2340)$ & $0(0.000)$ & 278 & 0.883 & 0.117 \\
\hline
\end{tabular}

Table 2: He, Ho, PIC and Ne of KIF-1-P3 locus in goat breeds

\begin{tabular}{lcccc}
\hline Breeds & $\mathrm{Ho}$ & $\mathrm{He}$ & $\mathrm{Ne}$ & $\mathrm{PIC}$ \\
\hline Xinjiang goat & 0.7082 & 0.2918 & 1.4120 & 0.2492 \\
Nanjiang cashmere goat & 0.6535 & 0.3465 & 1.5302 & 0.2865 \\
Bogeda cashmere goat & 0.7935 & 0.2065 & 1.2602 & 0.1852 \\
\hline
\end{tabular}

Ho: Gene homozygosity; He: Gene heterozygosity; Ne: Effective allele numbers; PIC: Polymorphism Information Content

Table 3: Chi-Square analysis of genotype distribution at KIF-1-P3 locus

\begin{tabular}{lcll}
\hline Breeds & $\begin{array}{c}\text { Xinjiang } \\
\text { goat }\end{array}$ & $\begin{array}{c}\text { Nanjiang } \\
\text { cashmere goat }\end{array}$ & $\begin{array}{c}\text { Bogeda } \\
\text { cashmere goat }\end{array}$ \\
\hline Xinjiang goat & - & $13.220^{*}(0.001)$ & $11.283^{*}(0.004)$ \\
Nanjiang cashmere goat & & - & $26.70^{* * *}(0.000)$ \\
Bogeda cashmere goat & & & - \\
\hline
\end{tabular}

Above diagonal data showed p-value of genotype distribution below diagonal data showed $\chi^{2}$ of genotype; Value with * and ** differ significantly at $\mathrm{p}<0.05$ and $\mathrm{p}<0.01$, respectively

Table 4: Least square means for genotype of KIF-1-P3 locus in Xinjiang cashmere goat

\begin{tabular}{|c|c|c|c|}
\hline \multirow[b]{2}{*}{ Cashmere traits } & \multicolumn{3}{|c|}{ Genotypes (Mean \pm SE) } \\
\hline & $\mathrm{AA}$ & $\mathrm{AB}$ & $\mathrm{AC}$ \\
\hline Cashmere fineness $(\mu \mathrm{m})$ & $16.057 \pm 0.108$ & $16.229 \pm 0.167$ & $15.995 \pm 0.6590$ \\
\hline Cashmere thickness (cm) & $3.604 \pm 0.101$ & $3.377 \pm 0.157$ & $2.800 \pm 0.6190$ \\
\hline Cashmere yield (g) & $151.747 \pm 3.990$ & $146.903 \pm 6.207$ & $130.000 \pm 24.435$ \\
\hline $\begin{array}{l}\text { Body weight after } \\
\text { combed }(\mathrm{kg})\end{array}$ & $30.213 \pm 0.673$ & $27.581 \pm 1.047$ & $28.000 \pm 4.1230$ \\
\hline
\end{tabular}

allele Numbers $(\mathrm{Ne})$ and Polymorphism Information Content (PIC)) were shown in Table 2. According to the classification of PIC (low polymorphism if PIC valu e $<0.25$, median polymorphism if $0.25<$ PIC value $<0.5$ and high polymorphism if $\mathrm{PIC}$ value $>0.5$ ), $K I F-1$ gene in 3 Xinjiang local goats was all at low polymorphic level. $\mathrm{He}, \mathrm{Ne}$ and PIC of $K I F-1$ gene in Nanjiang goat population were higher than other two goat breeds.

Moreover, the $\chi^{2}$-test showed that the genotype distributions of KIF-1-P3 loci were in disagreement with Hardy-Weinberg equilibrium in Nanjiang goat breeds (Table 1 and 2). Analyses of variance indicated that various genotypes in the three Xinjiang goat breeds were highly significant $(p<0.01)$ (Table 3 ). However, Table 4 showed that there is no significant difference in Xinjiang goat breed between polymorphisms of the $K I F-1$ gene and cashmere production traits (fineness, thickness, yield and body weight after combing).

\section{DISCUSSION}

Current knowledge of the genetic control of fibre production in sheep and goats is reviewed with the focus at the molecular level (Purvis and Jeffery, 2007). In the past few decades, many fundamental researches are clear indication that sheep type 1 and type 2 in KIF genes are at 11q25 q29 and 3q1 4 q22 (Dolling and Brooker, 1966) with the type 1 gene about $4 \sim 5 \mathrm{~kb}$ in length and containing 6 introns and the type 2 gene about $7 \sim 9 \mathrm{~kb}$ in length and containing 8 introns (Powell and Rogers, 1996). However, the study about discussing the association between the polymorphism of KIF gene and production traits is little. This research attempted to detect polymorphism at $K I F-1$ gene in 3 goat breeds of Xinjiang in China. The result showed that there was a mutation (Genebank M23912: c.3212 C>T) at KIF-1-P3 locus. The discovery is the first reported in international goat. In addition, further analysis indicates that the mutation belongs to synonymous mutation but the SNP at KIF-1-P3 region may not be a causal mutation in KIF-1 protein. Moreover, the association between the polymorphism of $\mathrm{KIF}-1-\mathrm{P} 3$ region and cashmere production traits is not significant difference.

$\mathrm{He}, \mathrm{Ne}$ and PIC of $K I F-1$ gene in Nanjiang goat population were higher than other 2 goat breeds. Moreover, in Nanjiang cashmere goat breeds, the genotype distributions of KIF-1-P3 loci were in disagreement with Hardy-Weinberg equilibrium. This is probably because Nanjiang cashmere goat breed is the variety bred, the breeding of its descendant is artificial selection strictly. Figure 3 showed that there were 3 genotypes (named as genotype $\mathrm{AA}, \mathrm{AB}$ and $\mathrm{BB}$ ). However, the Bogeda cashmere goat populations only have genotype $A A$ and $A B$, genotype $B B$ was disappeared. There may be two reasons, first because the Xinjiang goat populations should only have genotype $\mathrm{AA}$ and $\mathrm{AB}$ and the other is because the samples of genotype $\mathrm{BB}$ could not be collected.

\section{CONCLUSION}

At KIF-1-P3 locus, there was a mutation (Genebank M23912: c.3212 C>T) and further analysis showst that the mutation belongs to synonymous mutation. The SNP at KIF-1-P3 region may not be a causal mutation in KIF-1 protein. In addition, KIF-1-P3 region is association with cashmere production traits (fineness, thickness, yield and 
body weight after combing) not significantly. The $K I F-1$ gene can not be used as a candidate gene for production traits. A further profound study is needed because the studies in this thesis are preliminary.

\section{ACKNOWLEDGEMENTS}

This study was supported by the project of key Science and Research Program of Xinjiang Education Bureau(GrantNo: XJEDU2009I13), GEF AppliedResearch Project (GrantNo: GEF052456CHA)., Xinjiang 11th 5 year plan key project of science and technology (Grant No 200731132-7), The project of National Key Technology R and D Program in the 11th 5 year Plan of China (Grant No 2008BADB2B05) and National Modern Agriculture Industrial System Project (Grant No. nycytx-40).

\section{REFERENCES}

Dolling, C.H.S. and M.G. Brooker, 1966. A viable hypotrichosis in polled dorset sheep. J. Hered., 57: 86-90.

Hatzfeld, M. and W.W. Franke, 1985. Pair formation and promiscuity of cytokeratins: Formation in vitro of heterotypic complex and intermediate-sized filaments by homologous and heterologous recombinations of purified polypeptides. J. Cell Biol., 101: 1826-1841.

Hocker, H., 2002. Fibre Morphology. In: Wool: Science and Technology, Simpson, W.S. and G.H. Crawshaw (Eds.). Woodhead Publishing Ltd., Cambridge, England, pp: 60-79.

Leeder, J.D., 1986. The cell membrane complex and its influence on the properties of the wool fibre. Wool Sci. Rev., 63: 1-35.

Nei, M. and A.K. Roychoudhury, 1974. Sampling variance of heterozygosity and genetic distance. Genetics, 76: $379-390$.

Nei, M. and W.H. Li, 1979. Mathematic model for studying genetic variation in terms of restriction endonucleases. Proc. Natl. Acad. Sci. USA., 76: 5269-5273.

Norusis, M., 2008. SPSS 16.0 Guide to Data Analysis. 2nd Edn., Upper Saddle River, Prentice Hall, New Jersey, pp: 1-34.
Powell, B.C. and G.E. Rogers, 1996. The role of keratin proteins and their genes in the growth, structure and properties of hair. Exp. Suppl. Format. Struct. Hum. Hair, 78: 59-148.

Powell, B.C., 1996. The keratin proteins and genes of wool and hair. Wool Technol. Sheep Breed., 44: 100-118.

Pruet,, N.D., T.V. Tkatchenko, L. Jave-Suarez, D.F. Jacobs and C.S. Potter et al., 2004. Krtap 16, characterization of a new hair Keratin-Associated Protein (KAP) gene complex on mouse chromosome 16 and evidence for regulation by Hoxc13. J. Biol. Chem., 279: 51524-51533.

Purvis, I.W. and N. Jeffery, 2007. Genetics of fibre production in sheep and goats. Small Ruminant Res., 70: $42-47$.

Rippon, J.A., 1992. The Structure of Wool. In: Wool Dyeing, Lewis, D.M. (Ed.). Society of Dyers and Colourists, Bradford, England, pp:1-51.

Rogers, M.A., H. Winter, L. Langbein, R. Bleiler and J. Schweizer, 2004. The human type I keratin gene family: Characterization of new hair follicle specific members and evaluation of the chromosome 17q21.2 gene domain. Differentiation, 72: 527-540.

Rogers, M.A., L. Edler, H. Winter, L. Langbein, I. Beckmann and J. Schweizer, 2005. Characterization of new members of the human type II keratin gene family and a general evaluation of the keratin gene domain on chromosome 12q13.13. J. Invest. Dermatol., 124: 536-544.

Rogers, M.A., L. Langbein, S. Praetzel-Wunder, H. Winter and J. Schweizer, 2006. Human hair keratin-associated proteins (KAPs). Int. Rev. Cytol., 251: 209-263.

Sambrook, J. and D.W. Russell, 2001. Molecular Cloning: A Laboratory Manual. 3rd Edn., Cold Spring Harbor Laboratory Press, New York, pp: 49-56.

Schweizer, J., P.E. Bowden, P.A. Coulombe, L. Langbein and E.B. Lane et al., 2006. New consensus nomenclature for mammalian keratins. J. Cell Biol., 174: $169-174$

Zhao, Q., M.E. Davis and H.C. Hines, 2004. Associations of polymorphisms in the Pit-1 gene with growth and carcass traits in Angus beef cattle. J. Anim. Sci., 82: 2229-2233. 